\title{
Inbalt des siebenten Bandes (Teil III)
}

Texte:

1. Widmung von $A$ und $B$. . . . . . . . . . . . 3

2. Vorrede von $A B C$ und $D$. . . . . . . . . . . . 7

3. Nachricht wegen der dritten Auflage . . . . . . 10

4. Widmung und Vorerinnerung von $D$. . . . . . . 11

5. Das dritte Hauptstúck. Vom Auswendig Lernen . . 17

6. Rede des Hannibals an den Scipio . . . . . . . 19

7. Rede des scythischen Gesandten an Alexandern . . . 24

8. Rede, die von dem Cato im romischen Rathe, wider den Catilina hătte gehalten werden kónnen . . . . 29

9. Fleschiers Lobrede auf den Grafen von Turenne . . 34

10. Gúthers Rede auf Frau Lủbekinn . . . . . . . . 57

11. Das V. Hauptstúck. Von geistlichen Lehrreden, oder

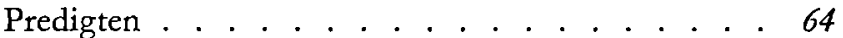

12. Der Tod der Mårtyrer, als ein Beweis der Evangelischen Wahrheit . . . . . . . . . . . . . 72

13. Oratio inauguralis academica de utilitate Poetae Philosophi . . . . . . . . . . . . . 94

14. Oratio inauguralis academica de utilitate et necessitate metaphysicae . . . . . . . . . . . . . . 110

15. Rede wieder die homiletischen Methodenkúnstler 122

16. Rede wieder die so genannte Homiletik . . . . . . 131

Variantenverzeichnis . . . . . . . . . . . . . . 139

Nacbwort des Herausgebers . . . . . . . . . . . . . . 243

Quellenverzeichnis . . . . . . . . . . . . . . 251 
